\title{
$\mathrm{Nd}: \mathrm{YAG}$ レーザー照射後の創傷治癒 \\ 一皮膚微小循環系への影響一
}

\section{Quantitative Studies on the Effect of Nd:YAG Laser Irradiation}

加藤麦夫, 深谷昌彦
各務和宏, 倉 内䇏

Mugio KATO, Masahiko HUKAYA, Kazuhiro KAKAMI and Jun KURAUCHI

愛知学院大学歯学部第 1 口腔外科学教室

Usually "total joule $(\mathrm{J})$ " or "energy density $\left(\mathrm{J} / \mathrm{cm}^{2}\right)$ " has been used as a unit expressing laser effect. However, there is virtually no data on the relationship between laser effect and constant total joule irradiation camed out under a set of certain conditions.

To obtain such basic data for laser irradiation, quantitative and successive studies were performed on the blood flow kinetics of microcirclation systems of skin wounds caused by $\mathrm{Nd}$ : YAG laser irradiation.

Male BALB/C mice (Mus muschlus) were used as experimental animals. The skin surface on the back was irradiated by Nd:YAG laser. Under the following set of conditions: focus distance was $14.0 \mathrm{~mm}$, total joules were at a constant $30 \mathrm{~J}$, the energy density was $30 \mathrm{~J} / \mathrm{cm}^{2}$. The joule curve (vertical line: output power; horizontal line: time) was determinded by combining output power and irradiation time, and 6 points on this curve were selected.

The intravascular volume and extravascular plasma wese measured using ${ }^{51} \mathrm{Cr}$-labeled red blood cells and ${ }^{125}$ I-labeled human serum albumin.

The present study showed that the effect on vital tissues irradiated by Nd:YAG laser varied under the different conditions at the 6 fixed points, even though the total joules were kept at a constant $30 \mathrm{~J}$. Accordingly, the unit "total joule" or "energy density" is inadequate for expressing laser effect. The results of this study also suggest that laser power (watt) tolerance by tissues exists. 
医用レーザーを使用する場合，そのレーザー の生体への影響を表現する単位として一般的に は total joule あるいは energy density が用い られている1,2)。しかし, 同一 joule でむ出力 と照射時間の関係から生体への影響は必ずしも 同じであるとは考えられない。とてろがての様 な考え方加らの基礎的研究はみられない。

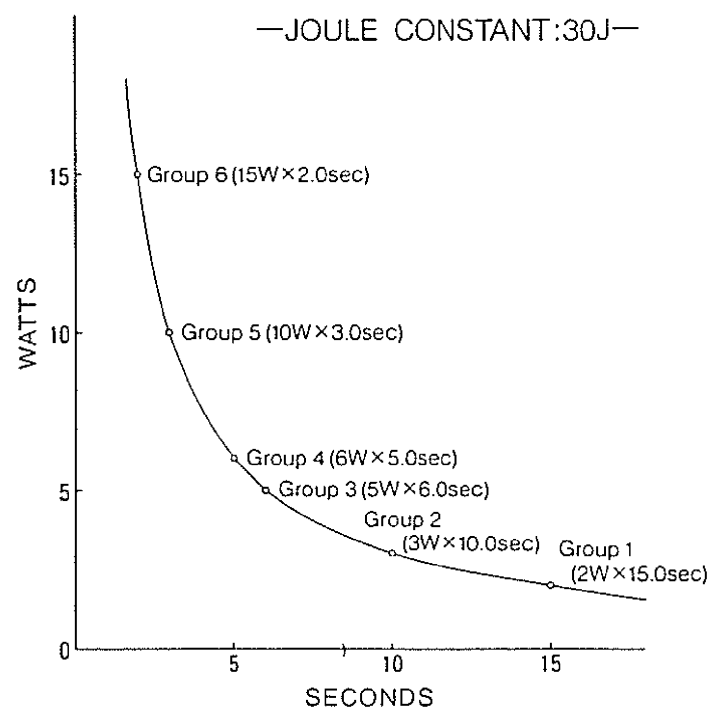

Fig. 1. The Joule Curve: The relationship between the laser output poer (watt) and the irradiated time (second). The curve represents the conbinations of watts and seconds, when the total energy (joule) is a constant $30 \mathrm{~J}$.

Fig.1は Joule 曲線を示している。縦軸は照 射出力をWatt で, 横軸は照射時間を Second で表している。著者らは総エネルギー量を $30 \mathrm{~J}$ に固定し，乙の曲線上に求められる出力と照射 時間を組合せ，照射条件を設定し，各 point の条件で生体への影響を考えることにした。レー ザーによる組織障害と回復に対する効果の観点 から影響を明らかにするととを試み，観察方法 としてレーザー照射後の微小循環の血流動態を 局所の赤血球とアルブミンの量的変化により検 索した。

\section{実験装置並びに実験方法}

レーザー装置はSLT. JAPAN 社製 Nd:YAG CONTACT LASER CL-50 を, ハンドピース は SLT. JAPAN 社製 SSRH-10を使用した。

$\mathrm{BALB} / \mathrm{C}$ 白色マウスの 6 8 週齢を用い，そ の背部皮膚を照射前日に予め剃毛し, 左側に照
射した。対照は剃毛処置のみで、レーザー照射 をしていないあのとした。

照射条件は group 1: $2 \mathrm{~W} \times 15.0$ 秒, group 2: $3 \mathrm{~W} \times 10.0$ 秒, group 3: $5 \mathrm{~W} \times 6.0$ 秒, group 4: 6 $\mathrm{W} \times 5.0$ 秒, group 5: $10 \mathrm{~W} \times 3.0$ 秒, group 6: 15 W×2.0秒の 6 群で，すべて total energy は $30 \mathrm{~J}$ である。レーザー照射は非接触式で, 照射距離 $14 \mathrm{~mm}, 1$ 回の照射によって直径 $3 \mathrm{~mm}$ の円形 照射面を作ることができ，9回の照射を行い約 $1 \mathrm{~cm}^{2}$ の正方形の照射面を作製した。なおレー ザー照射に際しては先端より $14 \mathrm{~mm}$ での出力 が設定した各々の值であることを OPHIR OPTICS 社製レーザーパワーモニター 30A-P を用いて確認した。

試料採取は照射後, 2 時間, 6 時間, 12 時間, 1 日，2日，4日，7日，14日，21日，28日目に 行った。各々心蔵穿刺により $0.2 \mathrm{ml}$ 採血した 後, 背部皮曆を Fig. 2 に示すようにレーザー 照射部を区域 I, 隣接部を区域 II, 周辺部を区域 III と分けて採取し, 周辺組織への影響を観察 した。

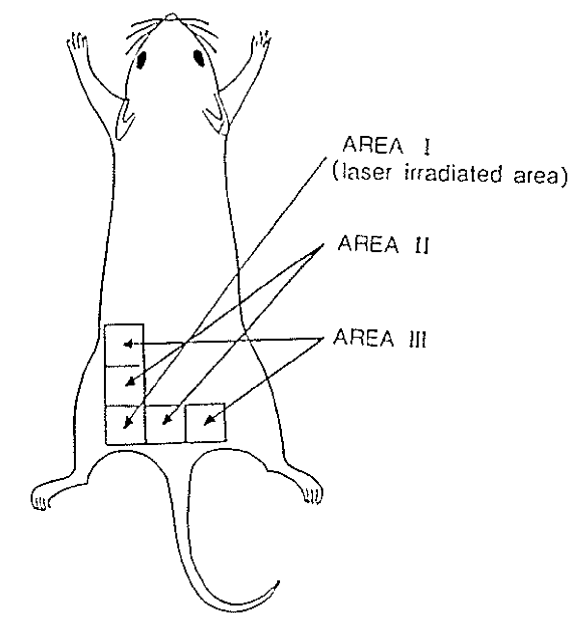

Fig. 2. The three areas that were picked after laser irradiation, Area I: laser irradiated region, Area II - III: adjacent regions (unirradiated areas)

背部皮雐微小循環の観察方法は Song ら ${ }^{3)}$ の 考案した血管内腔容積・血管外渗出プラズマ量 同時測定法を用いた。すなわち ${ }^{51} \mathrm{Cr}$ 標識赤血 球 $(125 \mu \mathrm{Ci})$ と ${ }^{125} \mathrm{I}$ 標識ヒト血清アルブミン $(20 \mu \mathrm{Ci})$ 混合溶液を測定各時期のそれぞれ 1 時間前にマウス尾静脈から注入し，血液と測定 
対照部の皮成を採取し，その中に含まれるラジ オアイソトープを Aloka 社製ウェル・シンチ レーションカウンター UNIVERSAL SCALAR MODEL TDC-501 亿て测定した。測定值は対 照を 1 として INDEX で表した。

\section{結果ならびに考察}

対照の血管内腔容積は $0.0041 \pm 0.0014 \mathrm{ml} / \mathrm{g}$ であった。この值を伹管内腔容積の正常値とし た。Fig 3〜8はレーザー照射後の血管内腔容 積に対する効果の実験各群における経時的な変 動をグラフに表したものである。

また対照の血管外渗出プラズマ量は $0.015 \pm$ $0.004 \mathrm{ml} / \mathrm{g} / \mathrm{hr}$ であった。この值を血管外渗出 プラズマ量の正常值とした。Fig. 9〜14 はレー ザー照射後の血管外㑢出プラズマ量に対する効 果の実験各群における経時的な変動をグラフに 表したものである。

微小偱環の变化を知るために血管内腔容積と 血管外渗出プラズマ量の関係を調べるととは重 要であると思わ机る。微小循環がレーザー照射 より受けた損傷と回復を逐日的にしかもその量 的変化を表すことができる。 $2 \mathrm{~W} \times 15.0$ 秒群で は微小循環系に変化はなく、レーザーの影響は 認めら扎なかった。 $3 \mathrm{~W} \times 10.0$ 秒群では微小循 環系に変化は生じるが，血管内腔容積は 2 日 目に，血管外渗出プラズマ量は 7 日目に正常化 しており，乙れは血管の変化は一過性であり， レーザーによる刺激効果であるといえる。これ 亿対し $5 \mathrm{~W} \times 6.0$ 秒群と $6 \mathrm{~W} \times 5.0$ 秒群での血管 内腔容積の 2 日目までの変化は血管外滲出プラ ズマ量の増加を伴い, 区域 Iは一旦減少し, 区 域 II は増加していた。さらに $10 \mathrm{~W} \times 3.0$ 秒群 と $15 \mathrm{~W} \times 2.0$ 秒群では血管内腔容積は区域 $\mathrm{I}$, 区域 II ともに初期には低下し，そして血管外 滲出プラズマ量む区域Iでは低值であった。こ れは初期において微小循環が破壊された結果で あり，後期に高値を示したのは回復過程とその 後正常域に戻る治癒過程を示すものである。乙 のととから同一Joule でも単位時間当りの Watt の大きい方が組織の障害は大きく，回復 屯遅れるととを示していると思われ，本実験に おける Nd:YAG レーザーの影響は Watt dependentであると考えられた。

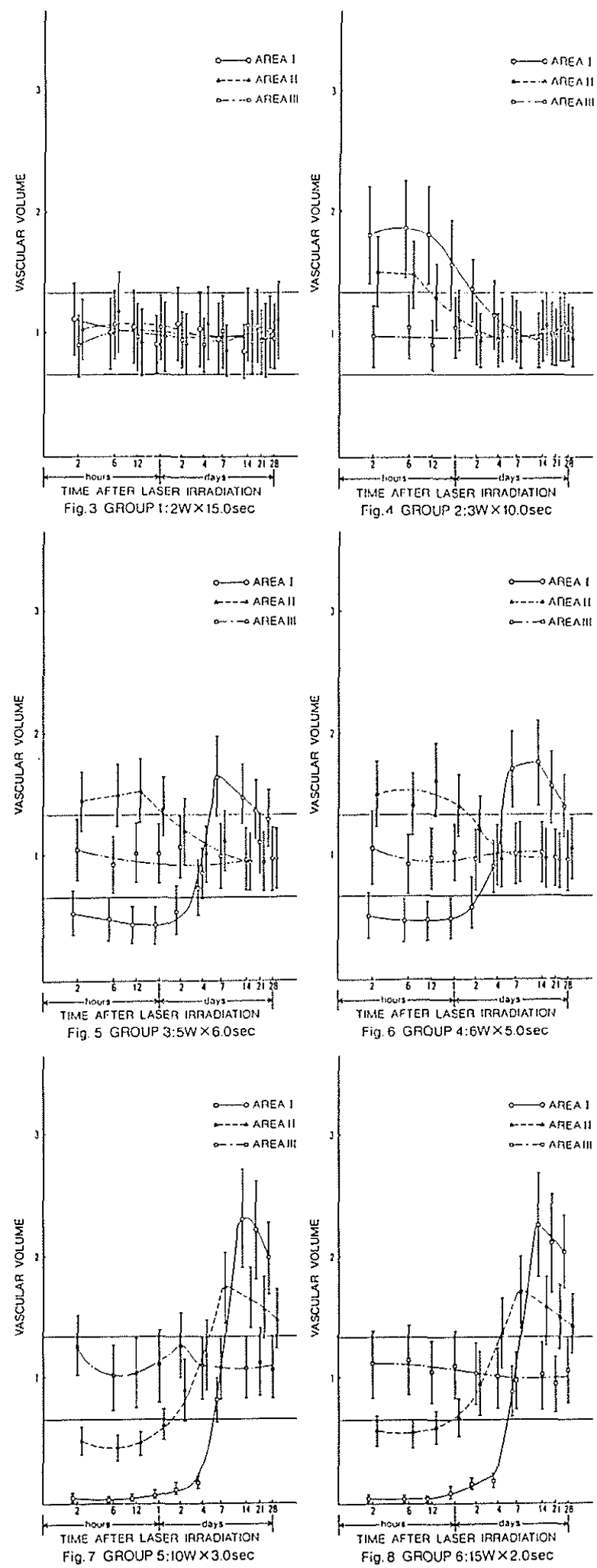

Fig. 3 8. Time course of changes in vascular volume in skin of mice after laser irradiation, expressed as relative value to the control. Each point is an average of 3 determinations and the bars are $1 \mathrm{SD}$. The two parallel lines show 1 SD of 10 determinations of the control group. 

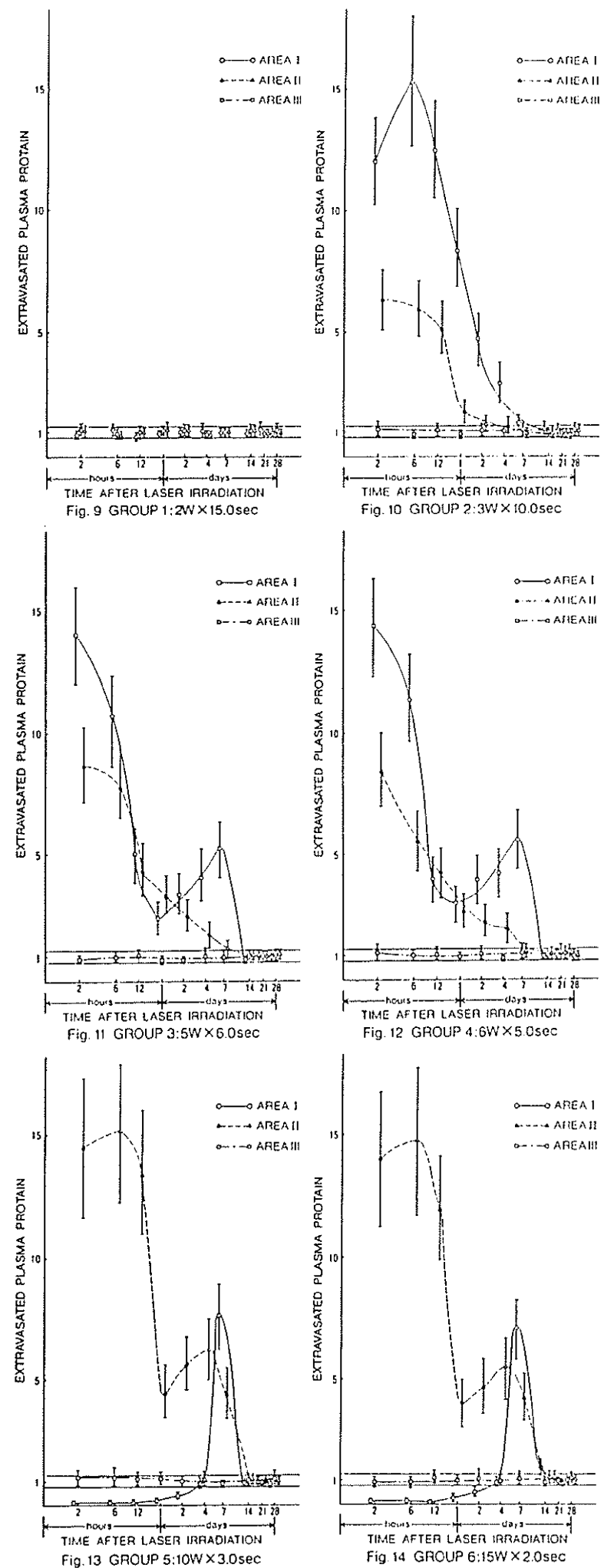

Fig. 9 14. Time course of changes in vascular permeability in skin of mice after laser irradiation, expressed as relative value to the control. Each point is an average of 3 determinations and the bars are $1 \mathrm{SD}$. The two parallel lines show $1 \mathrm{SD}$ of 10 determinations of the control group.
また $3 \mathrm{~W} \times 10.0$ 秒の条件を境にして血管が器 質的に変化を受けるのではないかと考えられる。 このととから微小循環系の耐レーザーパワー （ある一定のパワーを境にして組織が器質的に 変化をする，いわゆる組織の臨界パワーと考え る）という概念も成立すると思われた。

さらに従来，レーザー照射を行う場合にレー ザーの持つ energy と照射によって被照射体に 生ずる変化の大きさを表現する単位として total joule $(\mathrm{J})$ あるいは energy density $\left(\mathrm{J} / \mathrm{cm}^{2}\right)$ が用いられている。しかし本実験の“ジュール 曲線”で表されるように，同じエネルギー量 (J)であっても出力と時間の組合せが䀧なれば 生体の受ける変化も大きく異なるてとが本実験 により確認された。したがって総エネルギー量 によりレーザーの影響を考察することは不適当 ではないかと思われた。

\section{参考 文 献}

1) Y. Furuuchi: Experimental studied on the effect of low enegy $\mathrm{CO}_{2}$ laser on wound healing -The effect on the healing of full thickness skin defect-. J. J. oral and maxillofacial surgery. 33(1): 53-65, 1987. (in Japanese)

2) M. Ohyama, K. Katsuda, T. Nobori, M. Yamamoto, S. Furuta, M. Hashimoto and N. Daikuzono: Treatment of Head and Neck Tumors by Contact Nd-YAG Laser Surgery, Auris. Nasus. Larynx (Tokyo). 2(Suppl. II) : 138-142, 1985.

3) C. W. Song and Seymourh, L.: Quantitative Study of Vascularity in Walker Carcinoma 256, Cancer Research. 31: 587589, 1971. 